\title{
OPEN
}

Published online: 19 December 2019

\section{Author Correction: Integrating multi-platform genomic datasets for kidney renal clear cell carcinoma subtyping using stacked denoising autoencoders}

\author{
Tongjun Gu \& Xiwu Zhao \\ Correction to: Scientific Reports https://doi.org/10.1038/s41598-019-53048-x, published online 13 November 2019 \\ The Acknowledgements section in this Article is incomplete. \\ "We thank Dr. Xiaolin Li and Yanjun Li from University of Florida for their suggestions on the method used in \\ our study." \\ should read:
}

"We thank Dr. Xiaolin Li and Yanjun Li from University of Florida for their suggestions on the method used in our study. Publication of this article was funded in part by the University of Florida Open Access Publishing Fund."

(c) Open Access This article is licensed under a Creative Commons Attribution 4.0 International License, which permits use, sharing, adaptation, distribution and reproduction in any medium or format, as long as you give appropriate credit to the original author(s) and the source, provide a link to the Creative Commons license, and indicate if changes were made. The images or other third party material in this article are included in the article's Creative Commons license, unless indicated otherwise in a credit line to the material. If material is not included in the article's Creative Commons license and your intended use is not permitted by statutory regulation or exceeds the permitted use, you will need to obtain permission directly from the copyright holder. To view a copy of this license, visit http://creativecommons.org/licenses/by/4.0/.

(c) The Author(s) 2019 